\title{
The New Role of Contemporary Immigrants
}

\author{
Yang Zhao \\ Foreign Languages College, Beihua University, Jilin 132013, China
}

Keywords: Chinese American; Culture identity; The Joy Luck Club.

\begin{abstract}
With developing of globalization, the immigrants with double culture identities begin to play an important role in the economic and cultural communication of the world. The position of Chinese culture promoted in immigrants' heart, the new Chinese Americans begin to recognize their culture identities. Chinese American writer Amy Tan's The Joy Luck Club reflects this clash and change. From language, making friends and so on, this article points out the efforts and hardships for Chinese Americans who try to fuse into American society, summarizes the emerging reasons of Chinese American literature and looks forward to its future.
\end{abstract}

\section{Introduction}

Since the first Chinese immigrants set foot on the soil of California in the middle of the $19^{\text {th }}$ century, the Chinese immigrants began to multiply and live in the new land. From then on, both the Chinese who immigrated to America and their descendants who were born and had been growing there, had been living in between these two kinds of cultures: Chinese culture that passes on from generation to generation and the American culture that is entirely different. For more than one hundred years, there had been taken place great changes in the world; however, Chinese culture had been accompanied with the Chinese Americans in USA.

\section{Research}

When the old immigrant authors still wrote how the immigrants in USA adapted to and fused into the main culture, young authors made their characters begun to be interested in their own national culture from rejecting it invariably and accepting the powerful culture in that country they belong to. Chinese American authoress Amy Tan's work The Joy Luck Club reflected this delicate attitude and change of the concept of Chinese Americans.

Chinese American authoress Amy Tan was a dazzling new star in recent Chinese American literary world of USA undoubtedly. Amy Tan was born in Oakland in California in 1952. Her father, John Tan, had ever been educated in Beijing; he was a electricity engineer and clergyman. During the Second World War, he served for American intelligence agency and immigrated to America in 1947. Her mother was born in an island near Shanghai. Before the immigration, she had a period of unhappy marriage and gave birth to three daughters, but they were separated from and lost touch with each other during the War of Resistance against Japan.

Amy Tan spent her youth in miserable culture adaptation. Like most Chinese immigrated parents, her parents longed to see their daughter success in life, hoped her daughter can speak pure English, to become surgeon and amateur piano teacher, at the same time, they wished she could keep traditional Chinese culture, and be a Chinese. Their high expectation gave her great pressure, made her had rebellious sense, facilitated her to adapt to American culture actively, this process of assimilation was remembered with deep gratitude for her. "I always had the sense of shame and mean feeling in my heart. We had blind faith in so-called American nation melting-pot, in fact, we deliberately chose American things, such as hot dog while neglected things came from China.” Besides facing the pressure to be successful, Amy Tan suffered from losing her relatives. Her elder brother and father died of tumor in their brains. To shake off the shadows in her heart, her mother spent some time in Switzerland with her. In the early 1980s, she began to write lectures for salesmen and managers in companies, which was very successful. She had ever written "Telecommunications and You" for IBM. The economic success made her been lost in work fanatically, at last, she had to go to see 
psychological doctors. At this moment, she began to play the piano and read some works of American authors of contemporary and tried to write novels. In 1987, Amy Tan came back to China with her mother to visit her sisters. This traveling became a turn point in her thought. She had " a sense of reunion, like owning father and mother”. After returning to America, she took part in a writing class to promote her writing ability.

This novel described the daily life and divergence of mothers and their own daughters in four Chinese families in America. All four mothers immigrated to America from Chinese main land in 1949, they always got together to play mahjong pieces. When one of them met with wars in China, in order to forget these sufferings and divert her from loneliness, she played mahjong pieces with others and arranged some drinking to seek joy and luck; she even named it after "The Joy Luck Club". This is the origin of the title of this book. The four players and their own daughters told their own stories to us, so it reflected the life of Chinese Americans from multi-angles and multi-levels.

Immigrating to the USA from China means the loss of their former identities. In the novel, after one mother came to America, "I have no name; the year I was born was changed into dragon from tiger." She had to live on in a kind of new life style. Though she came to America with wonderful dreams, when stepping on this new land, all her dreams had gone like swans left a piece of feather only. What she had to face is a kind of completely new culture. In it, she can't find the sense of security; she always wanted to roll herself up into a safe corner which she considered. But she had to adapt to the new environment, to study American English with difficulties to adjust to American culture. These new immigrants gave up or inhibited the way of life and their customs consciously to imitate Americans intentionally, because they realized that "it is difficult to keep an unfixed Chinese face in America." Though they tried to smile as Americans, put on clothes in American style, in American eyes, they were still Chinese, which Americans can't understand forever. When they tried their best to fuse into American powerful culture, to adapt to American regulations, they were made a lesson. One mother who imitated the American life style went the seaside to spend her holiday, she lost her son.

In such a society that their inherent culture is in lower position obviously, these immigrants had to confine cultural attachment to their families. They hoped their children "can adapt to American atmosphere, but keep Chinese temperament”. However, they found their children were able to learn everything in America quickly. They turned a deaf ear to the Chinese temperament which their mothers taught. Mothers only sighed with feelings that it was incompatible as fire and water for adapting to American atmosphere and keeping Chinese temperament. When facing to Chinese culture (powerless culture) in families and American culture (powerful culture) out of families, children chose the latter one naturally, and had the strong intention to fuse into the powerful culture to become the members. So they tired of communicating with their own mothers in Chinese, and seldom spoke Chinese to adapt to their own mothers. While these mothers always spoke stammering English to cater to their daughters, to explain for something, these daughters laughed at mothers' English and their dull response. It showed that when powerful culture conflicted with powerless culture, the price was always sacrificing powerless culture; the languages they used in communications were one of the most evident aspects. At the same time, when mothers spoke in Chinese, even though daughters could understand, they always made an opposite understanding, which even had nothing to do with what mothers said. There was something difficult in communicating for two generations. The same language sign stood for different meaning in the eyes of mothers and daughters. At this moment, as a communicating tool Chinese had lost its role, to some extent. Though these daughters can't represent American completely, to some extent, the difficulty is the conversational obstacle between the East and the West. Both of them had a lot of misunderstanding. The problem was not the language signs, but the cultural connotation at the back of them. That people spoke the same language but there was language obstacle existed in them is the mutual misunderstanding between the Eastern and the Western culture. The daughters who had a smattering of knowledge of Chinese culture can't understand the depth of Chinese culture. On one hand, they can't understand, on the other hand, they didn't try to understand it. So naturally they were less and less familiar with their own culture. 
These immigrants who had both the powerless culture of their own nationalities and the powerful culture of their countries they belong to, which were on the edge of both two kinds of cultures in the first half of the $20^{\text {th }}$ century, were looked down upon by located countries and suspected by their own native countries. For both two kinds of cultures, they can't understand very well. They were considered as foundlings in both two kinds of cultures. With developing of the science, increasing of the transnational corporations, and the convenience of the traffic and correspondence of the world, these immigrants and their descendants played an important role in economic and cultural communication of the world. People began to evaluate them again, consider them as the important members of our society. When American society paid much attention to these immigrants of double culture identities, they began to think highly of their own powerless culture elements. In the past, they felt they were in the powerful culture society, any action reflected their native powerless culture was derided. At the present, there take place a lot of changes in global situation and sense, they find those derided points had their own glories. So they tried their best to develop the characteristics of double culture identities. The Joy Luck Club just reflects the delicate change of Chinese American sense.

From the analysis above, we can see the long process that Chinese Americans tried to fuse into American main society. It also showed that it wasn't easy for Chinese Americans to fuse into another civilization; they needed to define themselves and American this country unceasingly. Second, American main culture also defined and limited them. The emergence of Chinese American authors and achievements of Chinese American literature not only got the permission of American literary world, but also received warm reception. The reasons may be summarized to three main points:

First, Chinese American authors' sense of belongings. Chinese American authors were Americans, they were different from past “Chinese Americans”, they didn't lead on in American life style, they used American eyes, American thought and stood on America to look closely at China, to tell Chinese stories. They fused into America, had effect on American culture. Because of the yellow skin and black hairs, they naturally thought the contrast between the east and the west, the balance between traditional customs and realities. In these complicated connections, Chinese American authors may search for their belongings, find out their own superiorities, bear their responsibilities. Though America is a country full of immigrants, it isn't easy for minority Chinese American authors to try to fuse into American main society. The successors distinguished the traditional virtues and culture dross of their own nations, felt the elements of the eastern culture should be transformed, then could become controllable elements, as long as these successors took part in the transformation, they could play an important role. Their subjective conscious creations and objective result made them raised of sense of responsibility and belonging, which became their creative source.

Second, the literary volume of American multi-culture increased. In contrast to the Chinese nation who had a long history of more than 5 thousand years, the American nation is such a young nation only had a history of more than 2 hundred years created by European immigrants. In fact, American culture is a kind of "White" culture in English. Though Chinese American immigrants and their descendants became the important population composition, they were the minority; their culture was excluded by the main culture, suffering from oppression and indifference in the culture clash. Even though Americans boosted itself as "Melting-pot”, they can't show that Chinese American culture had fused into American culture, in fact, what had fused into the "Melting-pot" was the American culture--- "White "culture, the Chinese American Culture as the minority can't occupy a position in the metropolitan state. After the 1970s, especially in the 1980s, there were acute changes in American culture; the most famous one was the transformation from "Melting-pot" to "Multi- culture" which gave a golden opportunity to border culture rejected in the past.

Third, the writing core of American literature changed. Look back to American contemporary literary works, in the 1960s, authors were fond of describing family separation, one living in a solitary existence, the community lives, the dissolute experience and by drinking too much, making love, taking addictive drugs, leading a vagrant life to give vent to the depressed feeling of their hearts and to express their dissatisfaction with the real society. In the 1970s, many authors began to write family returning, reunion, the battle records, and thoughts on Vietnam War, etc. which added much delighted elements and courage for past “Beat Generation”. After the 1980s, in the literary works, 
there appeared the trend of realism. Multi-culture gave opportunities to these Chinese American authors, the change of writing focus made the creation of these authors have more chance to public their works.

\section{Summary}

With emerging of Chinese American literature, we can see that when carrying on American multiculture policies, they didn't realize to co-exist, there also appeared clash between border culture and main culture, the Chinese American authors who used to write in English were not so many, the community of Chinese America was growing bigger and bigger. Chinese American literature not only chose topics in the east, but also came out from it, like Black Literature, Jewish Literature and became the focal point to which American society paid much attention. With Chinese American authors' fusing into American society, the new superseding to old Chinese American authors, Chinese American literature would fuse into American main literature sooner or later, would go on enlarging new fields of creative works, would add more plentiful contents for world literature.

\section{References}

[1] Amy Tan, the Joy Luck Club, Vintage Contemporaries, 1991.

[2] Huang Tiechi, a Study of Contemporary American Novels, Xuelin Press, 2000.

[3] Li Gongzhao, an Introduction to 20th Century American Literature, Xi’An Jiaotong University Press, 2001. 